\title{
Interregional Labor Migration as a Tool to Increase Regional Labor Productivity: The Case of Russia
}

\begin{abstract}
Submited 10/01/19, 1st revision 20/02/19, 2nd revision 28/03/19, accepted 30/05/19
Panshin I.V. ${ }^{1}$, Markhaichuk M.M. ${ }^{2}$, Yares O.B. ${ }^{3}$

Abstract:

Purpose: The paper deals with the analysis of the influence of interregional labor migration in the Russian Federation on regional labor productivity.

Design/Methodology/Approach: Empirical analysis was conducted on the statistical data collected from the Federal State Statistics Service of the Russian Federation. The sample includes data on 85 subjects of the Russian Federation for the period 2011-2016. The study substantiates the impact of interregional labor migration in the Russian Federation on regional labor productivity and to form the tools for managing migration processes, ensuring its improvement.

Findings: The study showed that interregional differences in wages, the differentiation of the characteristics of labor markets in the region of residence and the potential region of employment, different transport accessibility and additional employee costs associated with staying in another region are the main economic reasons for interregional labor migration in the Russian Federation. The regression analysis confirmed hypotheses that higher level of labor migration from the region leads to a decrease in labor productivity in the region.

Practical Implications: Based on the empirically derived relationships, authors created a set of tools for managing migration processes, ensuring their improvement, which can be used for the development of program documents at the regional and interregional levels.

Originality/Value: The main contribution of this study is the combination of deep statistical analysis and migration factors ' analysis to provide valuable conclusions in interregional labor migrations.
\end{abstract}

Keywords: Labor resources, labor migration, labor productivity, regions.

JEL codes: J24, J30, J61, O15, O18.

Paper Type: Research article in Special Issue dedicated to Russian Economy.

Section 4: Migration.

${ }^{l}$ PhD in Economics, Associate Professor, Rector's Assistant for Development Programs, Head of Board of Research Activity, Vladimir State University named after Alexander and Nikolai Stoletovs (VLSU), Vladimir, Russian Federation, panshin@vlsu.ru

${ }^{2}$ PhD in Economics, Associate Professor of the Commerce and Hospitality Department, Vladimir State University named after Alexander and Nikolai Stoletovs (VLSU), Vladimir, Russian Federation, m.marhaychuk@gmail.com

${ }^{3} \mathrm{PhD}$ in Economics, Associate Professor, Head of the Commerce and Hospitality Department, Vladimir State University named after Alexander and Nikolai Stoletovs (VLSU), Vladimir, Russian Federation, yaresolga@inbox.ru 


\section{Introduction}

Low labor productivity in the Russian Federation is one of the key obstacles to increase economic growth. Along with well-known reasons, such as low capital-labor ratio, insufficient automation of labor processes, a small share of innovative products (services) in the output structure, relatively low investment in the development of the material and technical base of production, organizational factors also affect labor productivity. One of them is the high level of operational load on labor resources in Russia.

If labor productivity in Russia is 2-2.5 times lower than in developed countries, the difference in wages is 5-6 times. The nominal annual working time fund of the average Russian is one of the highest in Europe. All of this suggests that the working people of Russia bear a higher operational burden in comparison with the inhabitants of Western countries. Due to this situation, it becomes profitable for an employer to attract a large number of low-paid employees. Interregional labor migration comes to the fore here as an additional regulator of the domestic labor markets of the Russian Federation subjects and a tool for managing labor productivity.

Labor productivity is the research object of many scientists and practitioners both in Russia and abroad. With regard to the study subject we should emphasize the works of foreign authors (Barr, 1995; McConnell and Bru, 1999; Clark, 2000; Kendrick, 1967; Samuelson, 2007; Solow, 1956; Solow, 1957), who investigated labor productivity as the main competitive advantage of an economic subject, formulated the concept of aggregate and factor productivity.

The work of Solow (1956) solved the problem of decomposing the growth of regional output into three factors: labor, capital, and technical progress with the hypothesis that the regional output can be described by the Cobb-Douglas production function, and the contribution of technical progress, as an unobservable value, can be calculated by a residual method. The proposed method (Solow, 1957) for calculating the contribution of the technological component to regional production was subsequently applied for the regions of the United States and England (Hulten and Schwab, 1984; Harris and Trainor, 1997) and also was tested on Russian data (Drobyshevsky and Glavatskaya, 2005).

In other studies (Nevima and Melecký, 2011a; 2011b), in order to take into account a wider range of productivity factors, authors proposed to evaluate the regional production function (dependence of regional output on a number of factors) using econometric methodology. The residues of the model were interpreted as contribution of technical progress ("Solow's remainder"). The authors apply this approach to panel data across EU regions, evaluating the fixed effects model, which are interpreted as indicators of competitiveness. 
Among domestic authors who evaluated the influence of various factors on the dynamics of labor productivity at state and regional level the following should be highlighted (Bessonov et al., 2009; Drobyshevsky and Glavatskaya, 2005; Ilyin et al., 2010; Mikheeva, 2014; 2015; Polterovich, 2014; Suvorov and Timarsuev, 2014; Voskoboinikov and Gimpelson, 2015; Zaitsev, 2013; 2016).

Issues relating to interregional migration are widely covered in recent studies (Benier and Corcoran, 2018; Biagi and Dotzel, 2018; Capasso et al., 2012; Cao et al., 2018; Denisov, 2018; Gerolimetto and Magrini, 2018; Rivera-Batiz, 2018; Simonen, Svento, Karhinen and McCann, 2018), including labor migration (Arntz, 2010; Ding, 2009; Haussen and Uebelmesser, 2018; Moshiri and Moghaddam, 2018; Sanchez-Moral et al., 2018; Simonen et al., 2018; Zhou et al., 2018). Scientific community also pays attention to the problem of migration regulation (Bystrov, Shishaev, Malygina and Khaliullina, 2018; Molinder, 2018; Nuraeny, 2018; Prytkova, 2017). Despite the many factors influencing labor productivity studied in the literature, it should be noted that the change in the numerical and qualitative structure of the labor force of the territory due to interregional labor migration as an independent factor has not yet been considered. The purpose of the study is to substantiate the impact of interregional labor migration in the Russian Federation on regional labor productivity and to form the tools for managing migration processes, ensuring its improvement.

\section{Interregional Labor Migration and Labor Productivity}

In economic practice, labor productivity (LP) is most often measured per hour of hours worked and for the region is defined as the ratio of the volume of produced goods (services), gross value added or gross regional product to the number of man-hours worked. Estimation of LP by the volumes of goods (services) produced is simpler and applicable for analyzing the dynamics of economic growth in a region, when certain indicators are compared with themselves at different periods of time. Interregional comparisons of LP using the volumes of goods (services) produced in the numerator will be correct only if the material consumption of the products of the compared regions is approximately equal, or the regions have a similar specialization. Other variants of interregional comparisons will give a highly distorted picture of LP estimates, since in mining regions the output volume is greatly influenced by natural rent, which is absent in regions specialized in manufacturing industries. The cost structure in agricultural regions will strongly differ from industrial or resort-tourist areas. In this regard, it is reasonable to use gross value added (GVA) or gross regional product (GRP) for interregional comparisons of LP.

In accordance with the current methodology for calculating the "Labor productivity index" approved by the Federal State Statistics Service of the Russian Federation (Rosstat) Order No. 274 dated April 28, 2018 (On Approval of the Methodology for Calculating the Indicator "Labor Productivity Index", 2018) GVA represents primary income of the residents involved in the production of goods and services, and is 
calculated at the level of industries as the difference between the production of goods (services) and intermediate consumption.

According to the same methodology GRP represents the value of goods and services produced in the region for final use, and is calculated by the production method as the difference between output and intermediate consumption in basic prices. The amount of GVA of enterprises of all industries forms the GRP. The rate of output per employee is often used in the calculations of labor productivity. And if in inter-country comparisons this indicator often gives a distorted picture, since, as is known, the duration of the working day, working week, the number of weekends and holidays, traditions of the organization of the labor process, etc., in different countries can vary significantly, then for inter-regional comparisons the production is the relevant indicator. It turns out that any changes in the GRP and the number of people employed in the region affect labor productivity. The number of people employed in addition to the internal state of the labor market is significantly affected by interregional labor migration.

In our study, interregional labor migration will be understood as a type of migration that characterizes the totality of movements of people associated with employment from one subject of the Russian Federation to another. It turns out that the employment of a person living in one region, at an enterprise located in another region, should reduce the denominator in the formula of labor productivity and positively affect its value in the region of departure. However, in practice, the picture is quite different.

The presence of unoccupied jobs in the region of arrival has a negative impact on the volume of products (services) and, as a result, GRP. Taking into account the comparison of labor costs, the output of the employed migrant may be higher than the average output in the region of departure and in the region of arrival. Attracting skilled and highly motivated labor migrants from other regions increases productivity. In the region of departure, labor productivity, respectively, falls, as the negative impact of labor outflow on GRP is stronger than the decrease in the number of employees.

Let us point out the main economic reasons for interregional labor migration in the Russian Federation:

1. Significant interregional differences in wage levels. According to official Rosstat data for August 2018, the average monthly nominal accrued wages of employees of organizations in Russia amounted to 41,364 rubles. However, if we consider this indicator in the context of the subjects of the Russian Federation, then interregional differences can be more than four times - from 22,873 rubles in the Kabardino-Balkar Republic to 91,654 rubles in the Chukotka Autonomous District. Within the regions of one federal district, the differences are also significant, for example, in the Central Federal District - 3.1 times (Ivanovo Region - 24,941 rubles, Moscow - 77,618 rubles). The smallest differences in the level of wages by region were recorded in the North Caucasus - 1.3 times (Kabardino-Balkar Republic - 22,873 rubles, Stavropol 
Territory - 29,001 rubles), Privolzhsky Federal District - 1.3 (Saratov Region 26,075 rubles, Perm Region - 34,257 rubles) and the Southern Federal Districts of the Russian Federation - 1.4 (Republic of Kalmykia - 24,802 rubles, Volgograd Region $-29,490$ rubles).

The higher is the differentiation in the level of wages in the regions of one federal district, the higher is the level of internal interregional labor migration. In regions of the federal districts of the Russian Federation, where wage differences are less noticeable, interregional labor migration to regions of another federal district, where wages are significantly higher, becomes attractive, and the difference will be able to cover additional costs associated with working outside the region of residence.

2. Differentiation of the labor markets characteristics in the region of the person's residence and the potential region of employment. These characteristics include:

- total labor market;

- availability of vacancies, including seasonal;

- unemployment rate;

- the activity of foreign labor migrants;

- $\quad$ support of employment by regional authorities, etc.

3. Transport accessibility determined by the geographical location of certain territories of the region and the availability of transport infrastructure. The population of the border areas of one region often finds a job at enterprises located in economically developed settlements of the neighboring region. Lower costs of time and money at the way from the place of work to the permanent place of residence are the reasons for this choice. The availability of high-speed rail transport also significantly influences opportunities of interregional labor migration. Often, a two-, three-hour transfer from one regional center to another becomes more preferable for an employee than even going to work within the territory of his region of residence.

4. Assessment of the employee's additional costs related to staying in another region (the cost of renting accommodation, meals, utilities, etc.). This reason is interconnected with differences in payments for labor. If the difference in the salary of the worker employed in another region covers the amount of his additional costs, then the decision can be made in favor of labor migration, and vice versa.

All these reasons together form interregional labor flows and determine the human resource potential of the territory.

\section{Analysis of the Interregional Labor Migration Impact on Labor Productivity and Labor Costs}


Regression analysis was applied in order to check the relationship between the volume of migration from the subjects of the Russian Federation and changes in labor productivity and labor costs. The following hypotheses were tested:

H1: Higher level of labor migration from the region is associated with a decrease in labor productivity in the region.

H2: The increase in the labor force in the region due to interregional labor migration leads to an increase in labor productivity.

H3: Higher level of labor migration from the region is associated with a decrease in labor costs in the region.

H4: The increase in the labor force in the region due to interregional labor migration leads to an increase in labor costs.

Empirical analysis was conducted on the statistical data collected from the Federal State Statistics Service of the Russian Federation. The sample includes data on 85 subjects of the Russian Federation for the 2011-2016 years.

Rosstat does not calculate the indicator "Labor productivity level" in the context of the Russian Federation subjects, limiting itself to calculations of the labor productivity index. Therefore, we used the labor productivity index $i L P$ as a dependent variable for testing hypotheses $\mathrm{H} 1$ and $\mathrm{H} 2$.

We calculated the labor cost index $i L E$ as an indicator characterizing labor costs to test hypotheses $\mathrm{H} 3$ and $\mathrm{H} 4$. Since Rosstat does not provide information on labor costs, the labor cost index can be obtained as a quotient from the division of the index of physical volume of GRP iGRP by the labor productivity index iLP (On Approval of the Methodology for Calculating the Indicator "Labor Productivity Index", 2013). Rosstat provides information on the following indicators on interregional labor migration:

- distribution of internal Russian labor migrants across the territories of their main work;

- distribution of internal Russian labor migrants in the subjects of the Russian Federation from which they leave.

These indicators are presented in thousands of people. We should use comparable indicators to build a model, therefore, it is necessary to bring the indicators on interregional migration to a percentage, since the labor productivity index and labor cost index are expressed as a percentage. It should be noted that if we calculate the labor migration index by dividing the number of migrants in the current period $M_{t}$ by the number of migrants in the previous period $M_{t-1}$, then using of such an indicator for the construction of the model would be incorrect, since the subjects of the Russian Federation have different amounts of labor force. And if, for example, the migration coefficient doubles, then in relation to the size of the labor force $L F$ it can be a very small percentage. Therefore, we calculated the percentage of migrants in the total 
labor force in the region to build a model. Then the following variables will be independent: the share of labor migrants from the subject of the Russian Federation in the total labor force of the subject of the Russian Federation sMout = Mout $/ L F \times 100$, where Mout is the number of migrants from the Russian Federation subject, and the change in the number of labor force in the Russian Federation subject due to interregional migration, expressed in percentage $d s M=(\operatorname{Min}-$ Mout $) /$ $(L F+M i n-M o u t) \times 100$, where Min is the number of migrants to the Russian Federation subject. Descriptive statistics for the above indicators are presented in Table 1.

Table 1. Descriptive statistics

\begin{tabular}{|l|c|c|c|c|c|c|}
\hline \multicolumn{1}{|c|}{ Variable } & Mean & Median & Maximum & Minimum & Std. Dev. & Observations \\
\hline$i L P, \%$ & 102.4738 & 102.3000 & 113.1000 & 84.30000 & 3.400229 & 478 \\
\hline$i L E, \%$ & 99.65565 & 99.70545 & 109.0452 & 94.98141 & 1.366467 & 478 \\
\hline $\begin{array}{l}\text { sMout, } \\
\%\end{array}$ & 3.411812 & 1.795569 & 17.45758 & 0.006149 & 3.586706 & 478 \\
\hline$d s M, \%$ & -2.026168 & -1.259239 & 20.81560 & -19.69503 & 5.578457 & 478 \\
\hline $\begin{array}{l}\text { Min, } \\
\text { thousands } \\
\text { of people }\end{array}$ & 30.95422 & 3.384444 & 1390.763 & 0.142511 & 136.6152 & 478 \\
\hline $\begin{array}{l}\text { Mout, } \\
\text { thousands } \\
\text { of people }\end{array}$ & 28.84344 & 14.80088 & 697.5998 & 0.002815 & 58.99785 & 478 \\
\hline $\begin{array}{l}\text { LF, } \\
\text { thousands } \\
\text { of people }\end{array}$ & 950.5522 & 639.3915 & 7233.835 & 22.58900 & 979.0387 & 478 \\
\hline \begin{tabular}{l}
$i G R P, \%$ \\
\hline
\end{tabular} & 102.1201 & 102.0000 & 116.2000 & 82.50000 & 3.637848 & 478 \\
\hline
\end{tabular}

Before starting the estimation of econometric models we need to make sure, that all variables are stationary. The search of econometric dependencies for the case of nonstationary data can lead to the construction of apparent regressions and give deliberately erroneous results. We tested all variables with Levin, Lin \& Chu unit root test for panel data to check existence of such a shift. The studied variables are stationary. All models, except model 4, are fixed-effect panel regression models. Fixed effects models were tested for redundancy of fixed effects. Also fixed effects approach is appropriate according to Hausman test. Model 4 is a panel regression model with random effects, which was confirmed by the results of Hausman test. Estimated econometric models are presented in Table 2.

Table 2. Model table

\begin{tabular}{|l|c|c|c|c|}
\hline Variable / Model & Model 1 & Model 2 & Model 3 & Model 4 \\
\hline Dependent variable & \multicolumn{2}{|c|}{ iLP } & \multicolumn{2}{c|}{ iLE } \\
\hline \multirow{2}{*}{ sMout } & $-0.902318^{*}$ & & $-0.211975^{*}$ & \\
\cline { 2 - 5 } & $(0.193591)$ & & $(0.067756)$ & \\
\hline
\end{tabular}




\begin{tabular}{|l|c|c|c|c|}
\multirow{2}{*}{$d s M$} & & $0.367394 *$ & & $0.055812 *$ \\
\cline { 2 - 5 } & & $(0.139890)$ & & $(0.016601)$ \\
\hline \multirow{2}{*}{ Constant } & $105.5684 *$ & $103.2183^{*}$ & $100.3778 *$ & $99.78960 *$ \\
\cline { 2 - 5 } & $(0.678251)$ & $(0.319080)$ & $(0.237386)$ & $(0.101519)$ \\
\hline R-squared & 0.297543 & 0.268550 & 0.465852 & 0.022672 \\
\hline Adjusted R-squared & 0.148160 & 0.112209 & 0.352261 & 0.020619 \\
\hline F-statistic & 1.991814 & 0.112209 & 4.101129 & 11.04214 \\
\hline Observations & 480 & 478 & 480 & 478 \\
\hline Note: Standard Errors are in parentheses. * stat. significance on 1\%. \\
\hline
\end{tabular}

All obtained models are significant at $1 \%$ significance level. The formulated hypotheses $\mathrm{H} 1-\mathrm{H} 4$ were confirmed. According to the obtained models, we can draw the following conclusions:

Model 1: $1 \%$ outflow of labor force from the region due to interregional labor migration leads to a decrease in the labor productivity index by $0.9 \%$.

Model 2: The increase in the labor force in the region due to interregional labor migration by $1 \%$ leads to an increase in labor productivity by $0.4 \%$.

Model 3: $1 \%$ outflow of the labor force from the region due to interregional labor migration reduces the labor costs index by $0.2 \%$.

Model 4: The increase in labor force in the region due to interregional labor migration by $1 \%$ leads to an increase in labor costs by $0.1 \%$.

The low labor migration elasticity of labor productivity growth is explainable for several reasons:

- attraction of labor migrants is characterized by a high level of staff turnover in enterprises, which negatively affects labor productivity;

- the additional time and financial resources related to attracting labor migrants also have a negative impact on labor productivity.

Labor costs can be reduced in the arrival region, since wages are often lower for migrants than for local residents. Migration can lead to increased unemployment in the region of arrival, as labor migrants displace more expensive local labor force from the labor market.

The increase in the number of labor force due to the influx of labor migrants from other regions can influence the dynamics of labor productivity with different elasticities. On the one hand, attracting skilled labor, ensuring the creation of a high level of value added, has a positive effect on the dynamics of labor productivity. However, scarce qualified specialists require high wages and other expenses related to their stay in the region, such as compensation for accommodation, travel expenses, etc. 
On the other hand, the recruitment of mass professions specialists from other regions with a lower salary level than offered to the residents of the region either leads to an increase in unemployment in the region of residence, or to additional costs associated with retraining and employment of their workforce. At the same time, attracting lowskilled and unproductive personnel to unfilled and low-paying vacancies can simply adversely affect the level and dynamics of labor productivity, both in terms of the number of employees and taking into account labor costs. It turns out that for the effective management of interregional labor migration, it is necessary to analyze other factors. One of such determining factors of interregional labor migration influence on labor productivity is the belonging of a labor migrant to a certain type of economic activity. We considered the structure of interregional labor migration in the Russian Federation by type of economic activity and compared it with the sectoral structure of the total gross value added of the Russian Federation subjects (Figure 1).

As Figure 1 shows, there are obvious disproportions in the distribution of labor migrants by sectors of the economy of Russian regions. Thus, manufacturing enterprises, which give the largest contribution to the gross value added of the regions (17.3\%), attract only $9 \%$ of all labor migrants from other regions. And, on the contrary, the most attractive for migrants sector "Construction", which accumulates $21.9 \%$ of the entire mobile labor force, provides a contribution to the GVA of only $6.3 \%$.

Figure 1. Analysis of the ratio of the structure of the employed population working outside the region by types of economic activity and sectoral structure of gross value added of the Russian Federation in 2016, \%

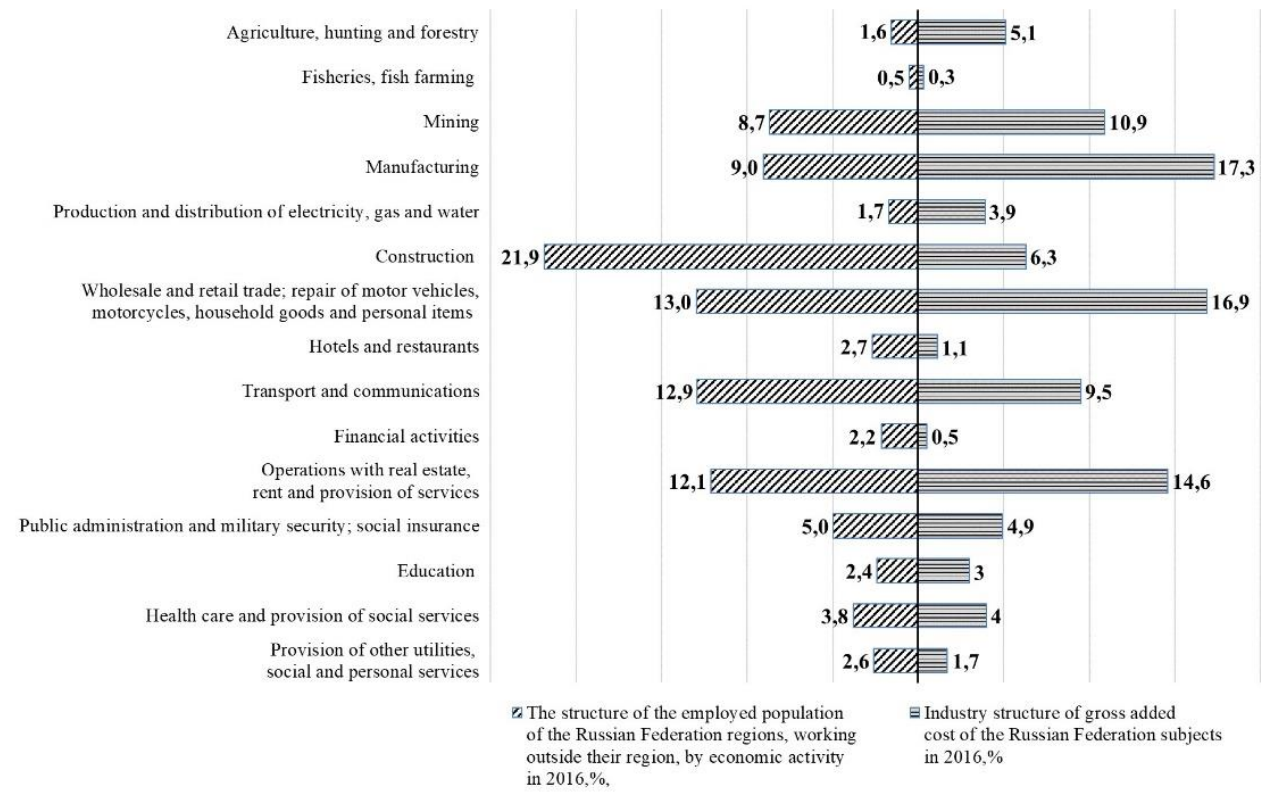


This indirectly confirms the hypothesis that high labor productivity in an enterprise does not always determine its attractiveness for labor migrants, who need both appropriate education, work experience, and a high level of motivation to work intensively for employment and effective work as in manufacturing. Low-skilled labor, the share of which, for example, in construction is quite high, becomes more attractive for employment of workers from other regions if the level of remuneration of labor becomes higher than in the region of residence. The more is a shift in the share of the industry towards labor migration in relation to the proportion of GVA, the less will be the contribution of interregional labor migration to the growth of labor productivity. The reverse pattern, such as in manufacturing, agriculture, hunting and forestry, reflects the high probability of interregional labor migration having a positive impact on labor productivity.

In 2017 23.4\% of internal Russian labor migrants (662.6 thousand people) were employed in construction, which is $1.5 \%$ more compared to $2016 ; 12.4 \%$ (351.6 thousand people) in trade; $11.8 \%$ (335.4 thousand people) in transportation and storage; $8.8 \%$ (250.8 thousand people) in extraction of minerals; $8.8 \%$ (248.4 thousand people) in manufacturing (decreased by $0.2 \%$ compared to 2016), which indicates the continuing trend of workers' choice for interregional labor migration of professions with low skills.

Having empirically proved that interregional labor migration has a significant impact on LP in the regions, we considered some issues of migration management. Managing interregional labor migration is a multifactorial and systemic process of regulating the incoming and outgoing flows of the working population moving between the subjects of the Russian Federation in search of work or performing labor functions outside the region of residence.

While in the international labor market one of the most common mechanisms for regulating migration flows is the quota of the number of specialists attracted from abroad, for interregional labor migration management tools and goals will be different. In contrast to restrictive measures for foreign labor migrants, all regions of the Russian Federation are economically interested in attracting skilled labor to their territory. In this regard, the system of management of interregional labor migration should be rather stimulating and include:

- informational support of the processes of attracting qualified specialists from outside the region;

- measures of targeted social support for families of specialists involved in the case of their joint stay in the region of employment;

- development of transport infrastructure, simplifying the movement of people from the place of residence to the place of work in another region;

- creation of interregional integrated structures that allow the joint use of qualified personnel in the territory of two or more regions; 
- measures to reinforce the demanded specialist and his further moving to the region for permanent residence.

Each of these tools for managing interregional labor migration becomes more effective when used in conjunction with others.

\section{Conclusions}

The main findings of the study are:

- the main economic reasons for interregional labor migration in the Russian Federation, such as interregional differences in the level of wages, differentiation of the characteristics of labor markets in the region of residence and potential employment region, different transport accessibility and additional employee costs associated with staying in another region were substantiated and systematized;

- the regression analysis confirmed hypotheses that higher level of labor migration from the region leads to a decrease in labor productivity in the region and an increase in the labor force in the region due to interregional labor migration leads to an increase in labor productivity;

- the reasons for the low change in the labor migration index elasticity of productivity growth in the region were identified;

- it is substantiated that one of the determining factors of interregional labor migration influence on labor productivity is the belonging of a labor migrant to a certain type of economic activity;

- five incentive instruments were identified for inclusion in the management system of interregional labor migration.

In general, Russian regions need to increase the attractiveness of their labor market for skilled labor migrants from other regions of the country, which will have a positive impact on labor productivity.

Further research prospects lie in the direction of comparing the effectiveness of attracting labor migrants to the region from abroad and from other regions of the Russian Federation, as well as introducing corrective factors into the models that take into account the specifics of a particular region.

\section{References:}

Arntz, M. 2010. What Attracts Human Capital? Understanding the Skill Composition of Interregional Job Matches in Germany. Regional Studies, 44(4), 423-441.

Barr, R. 1995. Political Economy. Moscow, International Relationships.

Benier, K., Corcoran, J. 2018. State of the Art and Future Challenges of Interregional Migration Empirical Research in Oceania, in Biagi, B., Faggian, A., Rajbhandari, I. and Venhorst, V. A. (eds), New Frontiers in Interregional Migration Research. Advances in Spatial Science. Cham: Springer International Publishing Ag, 125-147. 
Bessonov, V.A., Gimpelson, V.E., Kuzminov, Ya.I. and Yasin, E.G. 2009. Productivity and Factors of Long-Term Development of the Russian Economy. Moscow, Publishing House of the Higher School of Economics.

Biagi, B., Dotzel, K.R. 2018. Theoretical Advances on Interregional Migration Models, in Biagi, B., Faggian, A., Rajbhandari, I. and Venhorst, V. A. (eds), New Frontiers in Interregional Migration Research. Advances in Spatial Science. Cham: Springer International Publishing $\mathrm{Ag}, 21-47$.

Bystrov, V.V., Shishaev, M.G., Malygina, S.N. and Khaliullina, D.N. 2018, September. Development of the Forecasting Component of the Decision Support System for the Regulation of Inter-regional Migration Processes. In Proceedings of the Computational Methods in Systems and Software. Springer, Cham, 60-71.

Cao, Z., Zheng, X., Liu, Y., Li, Y. and Chen, Y. 2018. Exploring the Changing Patterns of China's Migration and its Determinants Using Census Data of 2000 and 2010. Habitat International, 82, 72-82.

Capasso, S., Carillo, M. R., De Siano, R. 2012. Migration Flows, Structural Change and Growth Convergence: a Panel Data Analysis of the Italian Regions. Manchester School, 80(4), 468-498.

Clark, D.B. 2000. Wealth Distribution. Moscow, Helios Association of Russian Universities.

Denisov, E.A. 2018. Migration Processes in Cities of the Russian North in the 1990s-2010s. Regional Research of Russia, 8(2), 158-168.

Ding, L. 2009. The Economic Consequence of Labor Mobility in China's Regional Development. Asian Economic Papers, 8(2), 85-114.

Drobyshevsky, S.M, Glavatskaya, N.G. 2005. Factors of Economic Growth in the Regions of the Russian Federation. Moscow, Institute of Economics, Politics and Law.

Gerolimetto, M., Magrini, S. 2018. State of the Art and Future Challenges of Interregional Migration Empirical Research in Europe, in Biagi, B., Faggian, A., Rajbhandari, I. \& Venhorst, V. A. (eds), New Frontiers in Interregional Migration Research. Advances in Spatial Science. Cham: Springer International Publishing Ag, 87-104.

Harris, R.I., Trainor, M. 1997. Productivity Growth in the UK Regions, 1968-1991. Oxford Bulletin of Economics and Statistics, 59(4), 485-509.

Haussen, T., Uebelmesser, S. 2018. Job Changes and Interregional Migration of Graduates. Regional Studies, 52(10), 1346-1359.

Hulten, C.R., Schwab, R.M. 1984. Regional Productivity Growth in US Manufacturing: 1951-78. The American Economic Review, 74(1), 152-162.

Ilyin, V.A., Gulin, K.A., Uskova, T.V. 2010. Strategic reserves of labor productivity growth in the regional economy. Economic and social changes: facts, trends, forecast, 1, 2438.

Kendrick, J. 1967. Performance Trends in the USA. Moscow, Sector of Foreign Economic Information.

McConnell, K., Bru, S. 1999. Economics: Principles, Problems and Policies. Moscow, INFRA-M.

Mikheeva, N.N. 2014. Regional Aspects of the Study of Labor Productivity. Region: Economics and Sociology, (1), 6-28.

Mikheeva, N.N. 2015. Comparative Analysis of Labor Productivity in the Russian Regions. Region Economics and Sociology, 2(86), 86-112.

Molinder, J. 2018. Why Did Swedish Regional Net Migration Rates Fall in the 1970s? The Role of Policy Changes Versus Structural Change, 1945-1985. Scandinavian Economic History Review, 66(1), 91-115. 
Moshiri, S., Moghaddam, M.B. 2018. The Effects of Oil Price Shocks in a Federation; The Case of Interregional Trade and Labour Migration. Energy Economics, 75, 206-221.

Nevima, J., Melecký, L. 2011a. Application of Econometric Panel Data Model for Regional Competitiveness Evaluation of Selected EU 15 Countries. Journal of Competitiveness, 3(4), 23-38.

Nevima, J., Melecký, L. 2011b. Regional Competitiveness Evaluation of Visegrad Four Countries Through Econometric Panel Data Model. In Liberec Economic Forum, 10(1), 348-361.

Nuraeny, H. 2017. Trafficking of Migrant Workers in Indonesia: A Legal Enforcement and Economic Perspective of Prevention and Protection Efforts. European Research Studies, 20(4B), 16-26.

On Approval of the Methodology for Calculating the Indicator "Labor Productivity Index". 2018. Order of the Federal State Statistics Service of the Russian Federation no. 274.

On Approval of the Methodology for Calculating the Indicator "Labor Productivity Index". 2013. Order of the Federal State Statistics Service of the Russian Federation no. 492.

Polterovich, V.M. 2014. Problems and Methods of Regional Diagnostics. Economics and Management: Scientific and Practical Journal, 1, 49-54.

Prytkova, Y.I. 2017. Foreign Experience of Regulation of Migration Processes by the Example of the Migration Policy of Canada. European Research Studies, 20(3A), 134.

Rivera-Batiz, F.L. 2018. International and Interregional Migration: Theory and Evidence. World Scientific Publishing Co. Pte. Ltd.

Samuelson, P. 2007. Economics, 18th Edition. Williams Publishing House.

Sanchez-Moral, S., Arellano, A., Diez-Pisonero, R. 2018. Interregional Mobility of Talent in Spain: the Role of Job Opportunities and Qualities of Places During the Recent Economic Crisis. Environment and Planning a-Economy and Space, 50(4), 789-808.

Simonen, J., Svento, R., Karhinen, S. and McCann, P. 2018 Inter-regional and Inter-sectoral Labour Mobility and the Industry Life Cycle: A Panel Data Analysis of Finnish High Technology Sector, in Biagi, B., Faggian, A., Rajbhandari, I. \& Venhorst, V. A. (eds), New Frontiers in Interregional Migration Research. Advances in Spatial Science. Cham: Springer International Publishing Ag, 151-179.

Solow, R.M. 1956. A Contribution to the Theory of Economic Growth. The Quarterly Journal of Economics, 70(1), 65-94.

Solow, R.M. 1957. Technical Change and the Aggregate Production Function. The Review of Economics and Statistics, 39(3), 312-320.

Suvorov, V.V. \& Timarsuev, M.V. 2014. Regional Aspect of the Analysis of Labor Productivity. Regional Economics: Theory and Practice, 46(373), 56-63.

Voskoboinikov, I.B., Gimpelson, V.E. 2015. Labor Productivity Growth, Structural Changes and Informal Employment in the Russian Economy. Questions of Economics, 11, 30-61.

Zaitsev, A.A. 2013. Regional Diagnostics and Sectoral Analysis of Labor Productivity. Federalism, 1(69), 1-26.

Zaitsev, A.A. 2016. Cross-Country Differences in Labor Productivity: the Role of Capital, the Level of Technology and Natural Rent. Economic Issues, (9), 67-93.

Zhou, Y., Guo, Y.Z., Liu, Y.S. 2018. High-level talent flow and its influence on regional unbalanced development in China. Applied Geography, 91, 89-98. 